\title{
THIRTY YEARS OF INDUSTRIAL RELATIONS LEGISLATION IN GHANA: 1941-1971
}

\author{
by Akilagpa Sawyerr
}

\section{INTRODUCTION}

Legislative regulation of industrial relations began in the then Gold Coast with the Trade Unions Ordinance (Cap. 91) of 1941. This was followed by a string of amending and repealing legislation, the last within our 30-year period being the Industrial Relations (Amendment) Act, 1971 (Act 383). It is proposed in this paper to examine the main stages in this legislative history, noting the factors which underlay specific options at different times. It is hoped that this will provide some insights into what goes into the enactment of legislation, and perhaps, even pose questions about the extent of the effectiveness of legislation ${ }^{1}$. To begin with, we review very briefly the history and politics of the period under discussion. This is followed by a summary statement of the main interests and factors that influenced the enactment of the main provisions. This summary is for the sake of convenience broken up into the main stages in the legislative history, each culminating in the enactment of one of the landmark statutes. In the final section some general comments are offered.

\section{HISTORICAL BACKGROUND ${ }^{2}$}

By the turn of the century colonial administration had become firmly established over Ghana (then the Gold Coast Colony, Ashanti, and the Northern Territories). As was its nature, colonial rule made little room for indigenous participation in major decisions affecting the economic and political life of the colony, except for a few grudging concessions. The clamour for more indigenous participation grew throughout the period, especially in the 1930's, taking a decisive form after World War II, with the formation of the Convention Peoples Party (C.P.P.) in 1949. From then on the anti-colonial struggle hotted up under the leadership of the mass-supported C.P.P., with its call for ,Self Government NOW'. Independence was achieved in 1957 under the C.P.P. Government of Kwame Nkrumah. The C.P.P. rapidly consolidated its control over the local political scene and declared Ghana a Republic within the British Commonwealth in 1960. Four years later Ghana was declared a one-party state, all party opposition to the C.P.P. being declared illegal. In February 1966 a military-cum-police coup d'etat removed the C.P.P. regime and established a National Liberation Council (N.L.C.) to govern the country. After three years this was replaced after parliamentary elections by a civilian government formed by the Progress Party (P.P.) under the leadership of Kofi Busia. In Jnuary 1972, the secound coup d'etat in Ghana's history removed the P.P. Government, replacing it with a military regime the National Redemption Council (N.R.C.).

\footnotetext{
1 Our concern here is primarily with what might be described as the surface features of state activity - what forces prompted the enactment of specific statutes and what short-run effects those statutes had on events in the field of labour relation. The longer-run movement of the colonial and post-colonial economies, which conditioned these superstructural phenomena - this we hope to deal with in a subsequent more comprehensive effort.

2 The description here is limited to the barest outline of political developments. For more detailed discussion reference must be made to relevant general works, such as: David E. Apter, Ghana in Transition (New York: Atheneum, 1963); David Kimble, A Political History of Ghana 1850-1928 (London: O.U.P., 1963); and Dennis Austin, Politics in Ghana (London: O.U.P., 1964).
} 
The history of the labour movement in Ghana is briefly told ${ }^{3}$. There is evidence of trade union activity as early as the 1920's, but because of the very small number of people in wage employment and the lack of organisation such activity was not significant before 1941. In that year only 4 unions were registered under the Trade Union Ordinance (Cap. 91), then newly enacted. This rose to 14 in 1945 when the first Trades Union Congress (TUC) was formed to co-ordinate their activities. These Unions were quickly drawn into the anti-colonial struggle in support of the political parties 4 . In 1948 they led the campaign to get the colonial administration to release from prison the leaders of the United Gold Coast Convention (UGCC) - , the Big Six - who had been arrested and detained for their part in the disturbances of that year. Two years later the TUC brought the workers out in a general strike to back Kwame Nkrumah's ,Positive Action' campaign for self-government. The aftermath of this campaign was the complete destruction of the TUC by the colonial government - its leaders throughout the country were arrested and detained, and many workers were dismissed en masse by both the government and the private expatriate firms. Out of the ashes of the TUC arose the Gold Coast Unemployed Association, later to become the Ghana Trade Union Congress (GTUC), to challenged the Gold Coast Trade Union Congress (GCTUC) which had been sponsored by the government to provide moderate trade union leadership. In 1953, a merger of the rival Congresses was effected under the auspices of the CPP, an indication of the obvious interest of the latter in a viable and ,friendly' trade union movement. This united front, never too solid, was soon to be fractured by the break-away of a few influential unions to form the Congress of Free Trade Unions (CFTU) in 1955. This congress derived support locally from the big expatriate firms and the political opposition to the CPP, and externally from the British T.U.C., the American AFL-CIO, and the International Confederation of Free Trade Unions (ICFTU). To counteract such centrifugal tendencies and consolidate the nationalist united front, the TUC leadership campaigned vigorously for legislated centralisation of the movement. In the end, and against considerable rank-and-file and union opposition, this was achieved with the passage of the Industrial Relations Act, 1958 (No. 56 of 1958), as amended in 1959 and 1960. The TUC thus became in law the sole representative of the labour movement in Ghana. From then on the TUC was linked more and more intimately with the CPP, its leaders being freely appointed to party, parliamentary and governmental positions, the Congress itself becoming one of the , auxiliary wings' of the CPP.

Following the coup of 1966 the leadership of the TUC was discredited and its intimate links with party and government disrupted. Government hostility to the TUC remained at a high level, culminating in the freezing of the assets of the TUC and the legislative destruction of its monopoly position in the labour movement in September 1971, the end of our , Thirty Years ${ }^{6}$

\footnotetext{
3 For detailed accounts from which much of the following material is derived see E.A. Cowan, Evolution of Trade Unionism in Ghana (Accra: Ghana Irades Union Congress undated); Leslie A Lacey, ,, A History of Railway Unionisri in Ghana“ (Accra: Institute of Atrican Studies, University of Ghana - M.A. Thesis); G.E. Lynd, The Politics of African Trade L'nionism (New York: Praeger, 1968): and I. Davies, African Trade Unions (London: Penguin, 1966).

+ See amnual Report on the Labour Department for the Year 19+8-49, p.9.
} 


\section{MAJOR LEGISLATION}

The major enactments in this period were:

A. Trade Unions Ordinance, Cap. 91;

B. Industrial Relations Act, 1958 (IRA), as amended in 1959 and 1960.

C. Industrial Relations Act, 1965 (Act. 299); and

D. Industrial Relations (Amendment) Act, 1971 (Act 383).

In what follows nothing more is attempted than the setting out of the main features of these statutes against the background of interest groups and events that accounted for them.

\section{A. TRADE UNION ORDINANCE, 1941-1950 (CAP. 91)}

\section{Main Interest Groups 5}

1. Colonial Administration: In response to Colonial Office pressure from London, the local administration was interested in regularising the position of the few weak trade unions then in existence, by making union activity lawful and requiring compulsory registration. By 1947 many unions had become engaged in overt anti-colonial political activity. This led the Administration to attempt to curb such activity and bring the unions within rules similar to those limiting the political activity of trade unions in Britain.

2. Trade Unions: As indicated above, these were initially few and weak. As they became better organised there was a greater push for increased wages and improved conditions of work under the leadership of the railway and harbour workers of Sekondi-Takoradi. Fourteen Unions came together in 1945 to form a Trades Union Congress ${ }^{6}$. This Congress was naturally opposed to curbs on union activity especially in the political field. In alliance with the Convention Peoples' Party (CPP) formed in 1949, it led a campaign against the government as chief employer and agent of colonial oppression. This campaign which culminated in the 1950 general strike in support of Nkrumah's call for national self-government, led to the dissolution of the congress and the arrest and detention of its leaders.

3. Private Firms: As employers of labour these firms, mostly foreign-owned, gave firm support to government regulations aimed at curbing the economic and political activity of the unions.

\footnotetext{
5 Further detail on relevant interest groups and the events discussed in Part III can be found in the works cited in nn.2 and 3 above, and also in J.K. Tettehgah.A New Chapter for Ghana Labour (Accra: Ghana Trades Union Congress, 1958). These are supplemented from newspaper reports, personal interviews and, especially for the years 1970 and 1971, personal observation. I would like to acknowledge the contribution of Mr. Anthony Norvor, now of the Law Reform Commission, who as a student acted as my Research Assistant for the project part of which forms the basis of this paper.

6 Partly as a result of the extreme political ferment of the period there was a marked rise in the number of registered trade unions and their membership. Thus from a total of 11,462 at the end of the period 1946-47, membership jumped to 30,458 during the following year. Again the numbers of registered trade unions went as follows: -

$1941-4$

$1945-14$

$1948-28$

1951- 88 (of which 65 were functioning)

1953- 97 (of which 81 were functioning)

1957-135 (of which 95 were functioning)

Source: Annual Reports of the Labour Department
} 


\section{Statutory Provision}

The original statute, the Trade Union Ordinance, 1941, was based on a general colonial model, with minor modifications and subsequent amendments. Its main features were that it

(i) made trade union activity lawful;

(ii) required the registration of every trade union; and

(iii) imposed strict limits on the use of union funds for political purposes, essentially restricting this to the financing of election campaigns.

\section{B. INDUSTRIAL RELATIONS ACT, 1958 (No. 56 of 1958)}

\section{Main Interest Groups}

1. Trades Union Congress (TUC): In the early 1950's the leaders of the re-established TUC operated very closely with the newly-formed government of the CPP. In sympathy with the ongoing struggle for political independence and economic development, they pushed for increased productivity of labour through industrialisation, to ensure job-creation and to ease unemployment. They wanted a strong TUC to bargain on something like equal terms with the big expatriate firms who employed many of its members, and to contain strike action as much as possible. They therefore sought to establish a full-time secretariat to mobilise and lead the workers. In this they were often frustrated by threats of internal splits and challenges to the leadership, especially from the relatively wealthy ,, house unions“, i.e. the union of workers of the big firms. To counteract these tendencies and connsolidate its control over the labour movement, the TUC leadership sought to strengthen the Congress. In 1957 the Executive Board of the TUC adopted what was known as ,, the New Structure“. This proposed the setting up of a highly centralised trade union movement on the pattern of the Israeli HISTADRUT. But voluntary centralisation proved impossible in the face of resistance from the influential ,,house unions“ and the powerful Railway Employees Union. The TUC leaders therefore pressed for legislation to strengthen their hands against their rivals for control of the trade union movement.

2. Individual Unions: Some distinction must be made between the position of the TUC leadership and that of individual unions since the two were not the same on all issues.

The ,New Structure“ was approved ,,in principle“ at the 14th Annual Congress in January 1958 , indicating the apparent support of the majority of the unions for amalgamation and central direction. But an influential minority was generally opposed to this. This opposition was led by the ,,house unions “ who were relatively well-off, and politically conservative. In this they had the support of their employers (concerned to break the united worker front), the British TUC, the American AFL/CIO, the International Confederation of Free Trade Unions (ICFTU) and the local political opposition to the CPP. Also in opposition was the Railway Employees Union, under the leadership of militant ,,leftists“ who felt they should lead the TUC instead of the then leaders, whom they considered too moderate. In addition to these two main groups were the Ghana Union of Teachers and the Federation of Government Industrial Trade Unions, of a generally rather conservative cast.

3. The Department of Labour: This branch of the Civil Service charged with labour matters, was in a dilemma. Whilst inclined against legislated centralisation, its business was the regulation of industrial relations. It drew on ideas underlying legislation in Israel, the U.S. and Canada. 
4. Private Employers: These were fiercely opposed to strong centralised leadership of the labour movement as this threatened their bargaining position vis-a-vis their workers, and their political position as expatriate capitalist enterprises. They therefore encouraged and supported the friedly house unions. This anticentralisation posture was, however, justified in public on the grounds that centralisation infringed the freedom of the individual workers and small unions, and gave Ghana a bad name abroad:

5. CPP. Government: The government had a lot in common with the TUC - common membership of CPP and TUC; history of political solidarity, and ideological affinity at leadership level. In consequence there was wide agreement between the CPP and TUC as to interests and methods of work.

But the CPP as the party of government had a necessarily wider rango of interests than the TUC. It was an employer, the employer of about $50 \%$ of all in recorded employment (1958), and was accountable to the entire nation for the production of goods and services. Though, probably under the influence of the Department of Labour, it initially favoured strong individual unions with the TUC as a coordinating agency, it was persuaded to support legislated centralisation by a) the general unrest in the country, b) the reluctance of private employers to honour collective agreements with individual unions, and c) the need to strengthen the hands of its political allies in the TUC against their rivals.

\section{Statutory Provision}

1. Preparatory Work: $:^{7}$ - Following a partially successful campaign for voluntary amalgamation of identical affiliated unions, the TUC resolved at its 13th Annual Congress in 1956 to send a delegation to Israel and West Germany to study union organisation. The report of this delegation formed the basis for proposals for a ,New Structure“ for the TUC which was adopted at the next Congress. The main features of the New Structure were: a) there were to be only 16 national unions; b) a check-off system (i.e. the deduction of union dues at source) was to be introduced; c) a social security and business enterprises fund was to be set up; and d) there was to be a system of compulsory arbitration for a 2-year period.

The Department of Labour on its part put forward a set of proposals to the Cabinet for a review of labour legislation. These included freedom of association for both workers and employers; prohibition of unfair labour practices; certification of unions for collective bargaining; procedures for conciliation, inquiry and arbitration; regulation of strikes and lockouts; a check-off system and the formal establishment of a National Advisory Council for Labour (NACL). The Cabinet considered the two sets of proposals and issued guiding principles for a comprehensive review of labour legislation. There were to be only 16 national unions: the TUC was to be etablished by law; and the formation of new unions was to be illegal except with the approval of the appropriate Minister on the recommendation of the TUC. These principles were then referred to the NACL (at that time operating without statutory backing) for its comments. This move to concentrate control over union activity in the hands of the TUC was vehemently opposed by certain interests, and letters of protest were received from the Ghana Union of Teachers, the Federation of Government Industrial Trade Unions

\footnotetext{
7 Information on preparatory work on this and the later statutes discussed in Part III was obtained mainly from Cabinet papers, files of the Labour Department and the Attorney-General's Office, and minutes of the meetings of the National Advisory Council on Labour.
} 
and the ICFTU. Inspite of such protests a Bill enacting these principles was put before Parliament and passed into law in December 1958. As subsequently amended in 1959 and 1960, this law governed industrial relations until the next major change in 1965.

2. Main Features: a) The TUC was formally set u pas a body corporate, sole representative of the trade union movement in Ghana. It was charged with the organisation and discipline of its member unions.

b) The TUC was constituted by 16 (originally 24) national unions. All other unions were to be dissolved, and no new ones were to be registered under Cap. 91 without the consent of the appropriate Minister.

c) A ,Union shop“ system was recognised. By this it became unlawful for an employer to keep in its employment for more than one month any worker not belonging to a recognised union. An exception was made in the case of the teachers and public servants.

d) Collective bargaining was to be conducted exclusively by such unions as were certified for the purpose by the Minister on the application of the TUC. Collective agreements thereby concluded were to cover all workers of the class specified in the certificate and their employers.

e) Dispute settlement procedures were set up. First recourse in case of industrial disputes was to a Standing Negotiating Committee made up of workers and employers covered by a certificate and approved by the Minister. From this body unresolved issues could be taken to a Conciliation Officer appointed by the Minister, and thence to compulsory arbitration. Any award on arbitration was to become effective and binding only after approval and gazetting by the Minister.

f) It was declared unlawful for workers not belonging to a certified union to go on strike or be locked out by their employers. In the case of workers belonging to certified unions they could lawfully go on strike or be locked out only after failure of conciliation and after a compulsory 4-week cooling-off period.

g)What constituted unfair labour practices were spelt out, and an Unfair Labour Practices Tribunal was proposed.

h) The check-off system was introduced. To implement this the Minister was empowered to authorise a union to request an employer to deduct union dues from a worker's wages and pay it direct to the TUC.

i) The Governor-General was given power to freeze the assets of the TUC and transfer them to a receiver, for cause.

The provisions of the Industrial Relations Act, 1958, as amended, outlined above achieved two main objectives. First, the TUC leadership was strengthened by the absolute control given to the TUC over unions and workers, and their assured access to finances through the check-off system. Secondly, the government for its part was assured of a measure of control over the labour situation through Ministerial control over the unions and the TUC itself and restrictions on the right to strike.

\section{INDUSTRIAL RELATIONS ACT, 1965 (ACT 299)}

\section{Main Interest Groups}

1. ICFTU and ILO: - The ICFTU, the international ,free world“ grouping of trades unions, to which the TUC was then affiliated had counselled against the adoption of the ,New Structure", and petitioned the government in vain against its enactment into law in 1958. It 
came to resent the increasingly nationalistic and ,,leftist" attitude of the Ghana Government and the TUC, and attempted to thwart the formation in 1961 of the All-African Trades Union Federation (AATUF) under the leadership of the Ghana TUC. The latter had by that time withdrawn its affiliation from the ICFTU. In 1962 a complaint was lodged by the ICFTU before the International Labour Organisation (ILO), to which Ghana belonged. It was alleged that the provisions of the Industrial Relations Act 1958 (as amended) (IRA) infringed the rights of workers to freedom of association because of a) legislated TUC monopoly of control over unions; b) compulsory union membership; c) Ministerial interference in TUC affairs; d) Ministerial control over certification for cellective bargaining; and e) the complete denial of the right to strike to certain categories of workers.

The ILO found the charges supported and recommended alterations in the law of Ghana to bring it in line with the Convention on Freedom of Association and Protection of the Right to Organise, 1948 (Convention 87), at the time unratified by Ghana.

2. CPP. Government: - The main interests of the government have been outlined above. After 1958 a number of factors came to complicate matters somewhat. In the first place the increasingly difficult economic situation in the country and the drive for industrialisation brought into the open the latent contradictions between the government and the rank and file of the workers. There was a severe clamp down on wages and a reduction in expenditure on social services: a tough budget was introduced, and a 5-10\% compulsory savings scheme was introduced in 1961, ostensibly to shift some of the burden of taxation away from the cocoa farmers and on to the urban wage workers. This resulted in a series of strikes, the most serious of which was the Railway and Harbour workers strike in Sekondi-Takoradi in $1961^{8}$. There was some evidence that the political opposition to the CPP was in some way involved in this. In the second place, construction workers at the Volta River Authority, an important state-owned undertaking, went on strike in February 1963. This prompted the Cabinet to exclude workers in state enterprises from the operation of the IRA. In response to worker protests, however, President Kwame Nkrumah personally intervened and secured the suspension of that decision. Thirdly, it had become a matter of acute embarrassment to Ghana government delegates to ILO meetings and conferences to be confronted by the international censure of the IRA and constant recommendations for a reduction in the TUC monopoly and governmental control of the labour movement. A final factor that might be mentioned was the unusual suscepitility of the CPP government by the mid-1960's to international pressure, especially from the camp of imperialism. This was because Ghana was then seeking help from bodies like the World Bank and the International Monetary Fund to ease her increasingly difficult economic situation. Further, she was at a delicate stage in the negotiations for securing U.S. private capital for the Volta Hydro-electric scheme which was then seen as the linchpin of her plan for industrialisation.

3. T.U.C.:- Now in effective control of the labour movement and in very close alliance with the government, the TUC backed the latter's tough economic measures and deplored the 1961 strikes. This was both a cause and a consequence of the increasing alienation of the TUC leadership from rank-and-file sentiment. But the TUC position was not unambiguous. Its leadership, inspite of its close alliance with the CPP, was nevertheless interested in reducing

8 This strike, started and led by the powerful Railway Employees Union, posed a criticalchallenge to the TUC and indeed the CPP government itself. It was therefore harshly suppressed and its leaders arrested and detained. See St. C. Drake and Leslie A. Lacey;, ,,Government versus the Unions: The Sekondi-TakoradiStrike, 1961“ in G. M. Carter(ed.), Politics in Africa (New York: Harcourt, Brace and World Inc., 1966). 
direct government control over the labour movement. It thus pressed for amendments to the IRA, particularly to substitute TUC for Ministerial control over such matters as membership and rules of the TUC and certification of unions. It also sought to extend the right to strike to uncertified unions and opposed the Cabinet decision to exclude workers in state enterprises from the operation of the IRA. Finally, TUC delegates to ILO meetings and conferences were subject to the same embarrassment and international pressure as affected the government delegates.

4. Individual Unions and Workers: - These became increasingly disenchanted with the „moderation" of the TUC leadership and, in face of their deteriorating material conditions, refused to accept TUC intercession on behalf of government. 'This disenchantment of the workers was sharply dramatised by the 1961 strikes. Led by the Railway and Habour Union based in Sekondi-Takoradi, and against the advice of the TUC, several Unions went on strike in Accra, Kumasi and other main towns. Ignoring the appeals of the TUC, their own union leaders, and finally President Nkrumah himself, the Sekondi strikers stayed out for two weeks. During that period some Kumasi workers went as far as to vote to disaffiliate from the TUC. The strike was only ended when the government resorted to the use of force, arrested the workers' leaders and detained them. Thereafter the workers remained uncowed and resentful.

5. State Enterprises Secretariat: - This body which had charge of the state enterprises, argued for the exclusion of the ,,spirit of negotiation and conflict" from enterprises already solvent. The improvement in the condition of workers in state enterprises and the introduction of grievance procedures in the new Conditions of Service, it was said, made it unnecessary to extend to those workers the protection of the IRA. This prevailed with the Cabinet, especially after the VRA workers strike of 1963, but was strenuously opposed by the TUC on the grounds that the conduct of state enterprise managements in the absence of IRA procedure had led to a deterioration in industrial relations and threatened productivity in those enterprises. This latter position led to President Nkrumah's suspension of the Cabinet decision in favour of the Secretariat.

6. Department of Labour: - The civil servants of the Department were impressed by the effectiveness of the IRA structure in encouraging amalgamation of unions and reducing the incidence of industrial strikes. At the same time, however, they respected the authority of the ILO and therefore proposed the removal of the sections of the IRA criticised in the ILO recommendations. Again, the Department opposed the exclusion of the state enterprise workers from the operation of the IRA because it threatened industrial relations, and, by favouring state enterprises, it would tend to frighten away foreign private enterprise. Finally, the exclusion would infringe ILO Convention 111 on Discrimination of Employment and Occupation.

7. Private Employers: - It would appear that private employers made little direct input into the making of labour policy in this period. In any event they were beneficiaries of the relative freedom from strikes that had accompanied the new structure of industrial relations.

\section{Statutory Provision}

\section{Preparatory Work: -}

The ILO observations on the ICFTU charges were considered by a special committee made up of two officials from the Department of Labour and two representatives of the TUC in May 1963. The report of this committee was next studie by a Presidential Committee on Af- 
rican Affairs, under the chairmanship of J.K. Tettegah. This Committee recommended the deletion from the IRA of those sections giving the Minister control over the TUC, but supported the retention of control by the TUC. In February 1964 the Cabinet considered a memorandum based on the reports of both committees and proposals made by the TUC and the Department of Labour. Needed changes in IRA were agreed and a final reply to the ILO was approved. It was also agreed that ILO Convention 87 be ratified. The Cabinet decision was briefly considered by the NACL before it was laid before Parliament. The amending bill was passed in June 1965.

2. Main Features:-a) The TUC was continued in existence as a representative of the trades union movement until the unions themselves decided otherwise. But the unions were no longer obliged to remain members of the TUC.

b) Any union was free to apply for registration under Cap.91 without the consent of the Minister.

c) The union shop was abolished. Thus a worker may belong to a union or not as he chose without jeopardising his job.

d) Any union, whether a member of the TUC or not, was free to apply to the Registrar, through the TUC, to be certified for the purposes of collective bargaining. The TUC was obliged to forward the application, and the Registrar to issue a certificate unless the employees in question were already covered by an existing certificate.

e) It was no longer necessary for the constitution of a Negotiating Committee to be approved by the Minister, and its rules needed only to be sent to the Registrar for his information. f) All unions were entitled without discrimination to go on strike or be the subject of a lockout, provided there had been a failure of conciliation and the expiry of the 4-week colling-off period. A strike or lock-out which did not meet these conditions was declared unlawful. g) The check-off system was preserved, but final say over the disposal of the funds was vested ultimately in the individual union rather than the TUC as before.

h) There was no express power vested in the President to freeze the assets of the TUC even for cause.

The effect of these provisions can be put thus:-

i) The individual worker was given greater autonomy. He no longer needed to join a union and pay union dues in order to get or hold his job.

ii) The individual union got more freedom too. It could exist outside the TUC structure and still enjoy union rights such as certification for collective bargaining; payment of dues by check-off and the right to strike. Even within the TUC an individual union had more initiative. It could opt out of the TUC, apply for certification without seeking anybody's consent, apply direct for payment of its dues by check-off and determine the ultimate disposal of those dues.

iii) Ministerial control of the trades union movement was greatly reduced. Thus the TUC was to make its own rules and provide for expenditure and audit without Ministerial approval, and there was no power to treeze its assets. Again, the Registrar, who replaced the Minister, was to exercise what were largely recording, rather than controlling, functions over such matters as certification. In any event, Ministerial consent was no longer needed for the registration of new unions. In a word, the provisions ensured a vastly diminished incidence of direct government control, and replaced legislated control by the TUC, with voluntary control. 


\section{INDUSTRIAL RELATIONS (AMENDMENT) ACT, 1971 (ACT 383)}

\section{Main Interest Groups}

1. Government of the National Liberation Council (NLC): - In February 1966 the CPP government was overthrown in a coup d'etat organised by elements of the Ghana Armed Forces and the Police. Leaders of the party and its, , auxiliary wings" were arrested and detained, and the NLC, made up of soldiers and policemen, was set up as the government. Among the immediate concerns of the NLC was the eradication of CPP influence in the labour movement and the depoliticisation of the latter. The NLC inherited many grievous economic problems and by its policies aggravated them. Its policy of drastic retrenchment of labour ${ }^{9}$ and the high cost of living, added to its persecution of their leaders, alienated the labour movement and led to a wave of strikes especially in 1968. The NLC's reaction was one of greater repression. It directed the arrest of the ,,instigators“, called for a review of the IRA to provide mandatory imprisonment for industrial offences and the replacement of the slow Arbitration Tribunal process with an Industrial Court. It also wanted labour officers, who were civil servants, to be able to intervene directly on the shop floor to settle labour disputes. 2. Government of the Progress Party (PP): - At the end of 1969 the PP formed a civilian government after its victory in parliamentary elections. It maintained the pressure on the unions and the TUC, a situation exarcebated by the deepening economic crisis. It rejected the TUC's claim for an increase in the minimum daily wage from $\mathrm{C} 0.75$ to $\mathrm{C} 1.00$, and introduced an austerity budget imposing among other things a $5 \%$ development levy. This led to a wave of strikes and threats of strikes in July and August 1971. Government Ministers and PP politicians publicly attacked the TUC and the unions and inaugurated a campaign for the further reduction in union power by the abolition of things like the check-off system. They encouraged the formation of a Ghana Confederation of Labour (GCL) in August to challenge the TUC's leadership of the labour movement. After declaring that it would not permit the TUC to be used for political purposes, and in anticipation of a general strike, the PP government in September froze the assets of the TUC for three months and enacted Act 383. The deepening economic crisis, its own political ineptness and the general disaffection of the people created the conditions in which yet another successful coup d'etat in January 1972 saw the replacement of the civilian PP government by a military/police junta.

3. TUC:-Following the 1966 coup d'etat, the TUC was subjected to punishing pressure by the NLC and PP governments as indicated above. The disaffection of the workers for all the reasons above stated was channelled through the TUC. It pushed for wage increases for the workers, opposed the austerity budget of 1971, and in particular the development levy. Its leaders travelled up and down the country mobilising workers support against the attack on its position, and government policies generally. This led to a wave of strikes, among which were the following: June 20 - July 13, 1971: workers at Tema Shipyard and Drydocks Corporation went on strike and ignored the Minister's ultimatum to return to work. This led to the dismissal of 400 workers.

July 4: Railway and Enginemen's Union began a strike for improved conditions of service, but called it off only after the intervention of the Secretary-General of the TUC.

July 13: Maritime and Dockworkers Union gave an ultimatum that if by the end of the month the dismissed Tema workers had not been reinstated they would call a nationwide strike.

9 Registered unemployment among wage and salaried employees in both the public and private sectors rose from 12,683 in January 1965 io 26,600 by June 1967: Report on the Labour Department for the year 1965-67 Table II (a). 
Mass demonstrations were threatened by workers in Accra, Kumasi and the West and Central Regions unless the Government withdrew the development levy, which had become something of symbol of the workers grievances against the PP government.

\section{Statutory Provisions}

\section{Preparatory Work:}

Immediately upon assuming power the NLC initiated a review of Act 299. Racommendations submitted by the Department of Labour were discussed by the NACL in May 1967. The latter rejected the Government's proposal that the TUC be dissolved altogether. A further review was ordered following the 1968 strikes. It was left to the PP administration to carry out a final review of the Act and enact this into law. This was inspired by the general labour unrest of 1970-71 and the government's discernment of a distinct threat to its very existence.

Early in 1971 the NACL appointed a subcommittee to carry out the review - but it never met. Instead the Ministry of Labour put out its recommendations. These were not discussed with the TUC as was customary, nor, also for the first time, was it referred to the NACL. It was discussed exclusively within the government bureaucracy - by a committee of the Minister of Labour, the Acting Chief Labour Officer and a representative of the Attorney-General. The resulting Bill was submitted to Parliament on September 6, 1971, and passed the same day under a "Certificate of Urgency“, that is, without the normal notices and delays that permit full considerationard discussion of legislation.

2. Main Features:

a) The TUC was dissolved and its assets vested in Receivers.

b) Any group of trades unions was to be free to form a congress or federation.

c) Workers were to be free to belong to any trade union of their choice, or to none. It was declared an unfair labour practice for any employer to penalise any workers for exercising this right.

d) Any trade union was free to apply to the Registrar to be certified for the purposes of collective bargaining. The Minister was given power to withdraw any such certificate if the union ceased to be representative of the workers covered by the certificate, or at the request of the employers' organisation.

e) The check-off was to be a matter of negotiation between individual unions and employers and deductions were to be made only if the Registrar was satisfied of the written consent of all workers covered.

f) The Minister was given power to suspend or prohibit a strike or lock-out for a period of 90 days, if:

i) it was considered prejudicial to defence, public order, the national economy etc;

iii) it threatened unlawful damage to property or

iv) it endangered the livelihood of many persons.

The Minister was then to appoint a Board of Enquiry to report back to him within 60 days. Upon receipt of this report the Minister was to make an order, binding on all affected parties, for the settlement of the dispute giving rise to the strike or lock-out. settlement of the dispute giving rise to the strike or lock-out.

g) Finally the Minister was given power to make regulations for implementing the main provisions of the Act. 
h) As this was an amending Act, all provisions in Act 299 not replaced remained in force. In sum, the effect of Act 383 was to destroy the TUC and reintroduce direct governmental control over the affairs of the labour movement.

\section{COMMENT}

The material here presented throws up a number of interesting questions. Among them the relevance of changes in the relationship between government and unions to the pattern of labour legislation; the influence of international agencies and opinion; and the degree to which changes in the law reflected and influenced conditions on the labour scene.

Before examining these questions, however, a word about the presentation of the material. It may be observed in criticism that the method of identification of interests groups in Part III invites the danger of oversimplification. For who can say that the concerns of all "Employers" were the same on all relevant matters in the periods discussed? Was the C.P.P. government ever a monolith? What variety of conflicting interests could one not find, were one to look closely at "the TUC". Conceding the validity of all these worries, we would only observe that our purpose in this paper is to excite discussion, not to present definitive conclusions, and for such a purpose a measure of simplification need not constitute a fatal flaw. In any event, it is hoped that the form of the presentation does not unduly vitiate the argument.

\section{Dominating Presence of Government}

The first feature of interest is the dominating presence of government on the labour scene for most of the period. This is not at all the situation in most of the Western capitalist countries, whom Ghana copies in so many things and on whom her economy is so dependent. In these countries labour relations are today primarily a matter of bargaining between big unions and big employers, with government playing only an indirect role. It must be noted, though, that, on the one hand, before the establishment of strong trade unions in those countries, say in nineteenth century England, government, through the law, did play a direct anti-worker role, whilst in the last few years, with policies of "wage and price freezes", governments in both the U.S. and England are stepping more directly into the labour arena. Our point is simply that in none of these countries has there been the same overtness of government involvement in all aspects of the labour scene as the history traced above indicates. The reasons are not far to seek. First, the state in Ghana is the employer of more than $50 \%$ of the nonagricultural work force in the country. It thus enters the bargaining process directly as employer. The second reason is that, here, unlike the situation in a straight capitalist country, the state is the prime mover in economic affairs. It is thus directly concerned with generating production and determining consumption patterns. It is in this regard that the relationship of the government of the day with the trade union movement is of interest. A trade union is mainly concerned with getting the best conditions for its members: a government has a necessarily wider constitutuency and wider responsibilities. To the extent that the rank and file membership of the trade unions and the government party coincide, and their respective leaders pull together, to that extent is the contradiction inherent in the relationship contained. This can be shown by reference to the period 1958-65 when, notwithstanding the 
Sekondi-Takoradi strike, there was relative calm on the industrial scene ${ }^{10}$ to such an extent that five years after the legislated centralisation of the trade union movement, both employers and civil servants, who had been hostile to the centralisation, were prepared to concede its effectiveness. This was the consequence of the fact that the C.P.P. government had more leverage with the leaders and members of the trade union movement, but was in its turn more amenable to pressure from them ${ }^{11}$. Contrast this with the colonial and post-1966 periods when there was such a lack of sympathy between labour and government that the latter was driven to attempt to legislate politics out of trade union activity.

A corrollary of the foregoing is the relative insignificance of the private employer in determining the fundamental pattern of labour legislation. From the middle fifties onwards his role became limited essentially to encouraging and sustaining splinter unions and movements in order to break the united front of labour and weaken its leverage with government and bargaining power against employers. True, employers were involved in the discussion of labour policy as members of the National Advisory Committee of Labour (NACL), but their views do not seem to have carried a great deal of weight ${ }^{12}$.

\section{Influence of External Bodies}

We next turn to the influence of external bodies and opinion. First there is evidence that the Colonial Office directive which led to the enactment of Cap. 91 was the result, in part, of ILO pressure to extend basic labour rights to the colonies. Secondly, from the beginning, Western trade unions like the British TUC, the American AFL-CIO and the international

10 The pattern of work stoppages during the period is most instructive. In the following table figures for some years are missing, while others cover more than twelve months, making precise comparison from year to year rather difficult. Nevertheless there is enough, it is believed, to give some indication of the incidence of industrial strife:

Period No of Stoppages

Jan.-Dec. 1947

Jan.-Dec. 1948

Jan.-Dec. 1949

Jan.-Dec. 1950

Jan.-Dec. 1951

Jan.-Dec. 1952

Jan.-Dec. 1955

Jan.-Dec. 1956

Jan.-Dec. 1957

Jan.-Dec. 1961

Jan. 1962-Sept. 1963 (21 months) 7

Oct. 1963-Dec. 1964 (15 months) 9

Jan. 1965-June 1967 (18 months) 56

July 1967-Dec. 1968 (18 months) 65

Sept. 1969-Sept. 1971 (24 months) 200*

Source: Annual Reports on the Labour Department for indicated periods, except for last figure, marked which was given by the then Minister for Labour in an interview published as a supplement to The Legon Observer, Vol. VI No.20, 1971.

11 For slightly differing views about the nature of this relationship compare Apter, op.cit., n. 2, Ch.15, passim, and Rolf Gerristen, ,,The Evolution of the Ghana Trades Union Congress under the CPP“" (mimeo: paper delivered to the 19the Annual Conference of the Ghana Historioal Society, at the University of Ghana, Legon, December, 1971).

12 This statement, limited to the question of direct influence on the formulation of labour relations policy, is not intended to cast any doubt upon the general influence of the business community on government policy in all aspects of national life. 
ICFTU had considerable influence on Ghana trade unionism. It was not till the rise of overt nationalist and leftist attitudes in the government and TUC that this influence diminished. But it seems to have been partially restored by the role of the ILO in getting the legislated centralisation broken up in 1965 - so anxious were both the government and the TUC not to appear at the 1965 ILO meeting without having amended IRA 1958. This ILO influence, through a Convention, then unratified by Ghana, is not a little difficult to understand. But perhaps a partial explanation can be found in the objective position of IRA 1965 in the history of labour in Ghana. This we deal with below.

\section{Role of Legislation}

We come finally to the role played by the various enactments in the developments of the period, and pose the general question of the effectiveness of legislation. We immediately run up against the problem that we only know one side of the story - how can we be certain what happened because of a particular piece of legislation unless we know what would have happened without it? We cannot be certain, we can only speculate.

The purpose of colonial legislation was to give recognition to local union rights whilst ensuring that the unions remained apolitical. This latter, positive, purpose failed of achievement because it ran counter to the general anti-colonial political activism of the time, which latter was itself obviously beyond the control of the colonial administration. In short, the attempt to legislate political unionism out of existence failed because it was not backed by adequate political action in the short run, and was perhaps doomed to failure any way in the long run. The next major piece of legislation was clearly more effective. IRA 1958-60 constituted an attempt to legislate for a strong centralised trade union movement in full acceptance of the inevitably political nature of trade unionism in Ghana at the time.Those opposing legislated centralisation - a few unions, the employers, ICFTU, the civil servants, and, for a time, the government - urged a course of voluntarism - voluntary amalgamations, voluntary checkoff etc. But objectively such voluntarism was unlikely to be effective, and the leaders of the TUC, and, later, the government, saw this ${ }^{13}$. There were too many centrifugal forces. There was first the desire of leaders of certain powerful unions to remain independent - those of the ,house unions', because they wished to retain their influence and control of their wealthy coffers: those of the Railwaymen's union, because they wanted to maintain their militancy and historical leadership of the trade union movement. There was, too, the presence of powerful groups with a vested interest in a divided trade union movement: the trade unions and confederations of the capitalist countries, to counteract the increasingly nationalist and anti-capitalist public stance of government and TUC; big firms, for the same reason, and also to weaken the bargaining position of the trade union movement; the opposition politicians, to break the CPP hold over the workers through control over an effective and all-embracing TUC. There can be little doubt that the TUC leadership before 1958 was not powerful enough to overcome these pressures by voluntarism. The 1958-60 legislation had the effect of tilting the balance in its favour: the outlawing of non-TUC unions and union shop bringing all workers formally within the TUC, and the check-off system giving it the financial muscle with which to consolidate its position. It is conceivable that non-voluntary centralisation

13 A process of voluntary mergers of small unions into larger national unions had had some success in the middle fifties. (See Report on the Labour Department for the year 1957-1958 pp. 21-23). But the real difficulty was to bring the powerful unions with the TUC. It was on this matter that the efficacy of voluntarism was called in question. 
could have been achieved in other ways such as by the arrest and detention of recalcitrant union leaders, victimisation of non-TUC workers, and economic backmail of awkward employers. But it is doubtful if such methods could have achieved the effectiveness and relative smoothness that legislation achieved.

It is absolutely essential to note the nature of the legislation and the conditions under which it proved effective. First, the legislation did not set out norms but sought to change structures, and backed the attempt by credible sanctions such as the refusal to register non-TUC unions, union shop - denying work to non-TUC workers, and payment of dues direct to the TUC by check-off method - thereby giving the TUC financial strength while denying it to any other unions. Secondly, the process of centralisation within the labour movement was bound up with the pattern of centralisation of political and economic power in the hands of the CPP government ${ }^{14}$, each process backing and sustaining the other. It was thus to be expected that a de facto one-party state (which Ghana was from 1960 onwards) should have a centralised labour movement. In short the legislation of 1958-60 was directing the labour movement along the path of all major institutions of the time, and that must account in large part for whatever success it had.

The converse of the lesson of the 1958-60 legislation is established by the effect of the 1965 legislation. In terms the latter sought to free both workers and their unions from rigid TUC and government control, but all it did was remove the legislative basis without disturbing TUC/CPP control over the trade union movement. The provisions were permissive and were not backed by any credible sanctions. The strength of the TUC and its hold over the unions no longer derived from its, legal' position, and the influence of the government over the labour movement through the TUC was assured by other than ,legal' means. Thus by 1965 , IRA had become irrelevant to the real situation in the labour movement and the country generally, and could be dispensed with. This in part explains the relative ease of the surrender to ILO pressure at that time ${ }^{15}$.

The 1971 Act carried its own lessons. There can be little doubt that it had a tremendous impact on the labour movement. It threw it into complete disarray, and deprived it of the vigorous TUC leadership which had ensured its effectiveness. It must be noted that the Act was not an isolated action of government, but was part of a general anti-leftist programme of PP government. It is not without significance that it was enacted at the same time as Act. 380, which prohibited any reference to Kwame Nkrumah, the deposed President of Ghana or the shouting of any slogan or symbol of the dissolved CPP, so insecure was the government! Whether all these moves would have been enough to break the hold of the TUC on the workers and the unions, and cause any lasting change on the labour scene can not now be told, since the 1972 coup d'etat came within four months of the passage of the Act.

To conclude, it is believed that this study provides some supportfor the thesis that legislation that does not accord with tendencies in the economic and social infrastructure of society is unlikely to be effective. On the other hand, where it does so accord and is also backed by adequate institutional changes, it is likely not only to be effective, but also, in its turn, to contribute to the fashioning of those tendencies.

\footnotetext{
14 See the general works cited in n.2 above.

15 It is instructive that during the crisis months of $1971 \mathrm{pp}$. government officials were prepared to ignore ILO objections to parts of proposed legislation that violated Convention No. 87. At a meeting of the NACL to consider the proposals, the Chief Labour (Officer stated that , the Committee was not bounds to accept the suggestions made by the (ILO) experts (since) Ghana was a sovereign state and. . . should be free to implement such decisions that would be appropriate . . . to its national circumstances". He went on. ,,ILO) Conventions should not be ignored, but. . . in applying them the interest of the country should be paramount " (Minutes of NACL meeting, July 19, 1971).
} 
should be an identity between the long-term interests of the state and the interests of the workers who are the leading class in the country. It was not always easy for union cadres, many of them Party members, to carry out Party policies on the one hand and to stand up for the immediate interests of the workers on the other hand. Some leading Party members like Liu Shaoqi and the "gang of four" tried to falsify the function of the unions in order to use them for their own purpose of usurping Party and state power. The basic principles for effective trade union work is to adhere to the leadership of the Party and to rely firmly on the masses. The basic constant task is to build an industrial army which is highly revolutionized and well versed in technical science. So far there have been two All-China Trade Unions Congresses of the PRC, the 7th (1953) and the 8th (1957). The 9th will be convened in October, 1978. The main task of the workers will be the implementation of the "four modernizations" in order to build a great and powerful socialist country with modernized agriculture, industry, national defence and science and technology before the end of the century.

\section{Thirty Years of Industrial Relations Legislation in Ghana: 1941-1971 \\ By Akilagpa SaWyer}

This review of legislation governing the organisation of trades unions in Ghana in the period 1941-71 deals with the ways in which the varying and conflicting positions taken by government administrative and political agencies, the unions themselves and external bodies like the British Tuc, the American AFL-CIO and the ICFTY influenced the form and substance of such legislation.

In the period before political independence the colonial administration sought to keep the labour movement out of political activity, whilst the CPP and the dominant elements in the movement worked for its active involvement. In pursuance of this latter object the CCP backed a process of amalgations to ensure the centralisation of control and the strengthening of the workers movement. This process came up against not only centrifugal tendencies within the movement itself, but also the activities of colonial administration, political opposition to the CPP, and the external bodies mentioned above. To counteract these forces the CPP government one year after independance enacted legislation concentrating power and funds in a centralised Trades Union Congress (TYC), which later became an "auxilliary wing" of the CPP. The role of the TYC was to bring the workers behind the government policy and ensure harmony on the industrial scene. After the overthrow of the CPP in 1966 the succeeding NLC and PP regimes sought to break the hold of CPP elements over the labour movement and weaken the opposition of the workers to their policies, by removing the legislative basis of TUC control and depoliticising the labour movement generally.

An interesting feature of this review is the light it sheds on the circumstances under which particular programmes of legislation are effective, in the sense of achieving their main objectives. For instance, the colonial administration's attempt to legislate the labour movement out of the political arena was a failure, while the CPP government was later succesful in legislating centralisation of the labour movement. The failure of the colonial attempt was largely due to the fact that it ran counter to the general anti-colonial activism of the time, and was not backed by adequate political action. The CPP success, on the other hand, is explained by the circumstance that the legislation was backed by such institutional arrangements as the denial of legitimacy and funds to non-Tuc unions, and formed part of the general move towards making Ghana a one-party state. 